\title{
Descriptive anatomy of artery of one-humped camel head (Camelus dromedarius)
}

\section{Introduction}

The arterial blood supply of the head of most domesticated animals has been studied by many authors Tayeb ${ }^{1}$, Smuts \& Bezuidenhout ${ }^{2}$, Blanco et al. ${ }^{3} \mathrm{O}^{\prime} \mathrm{Brein}^{4}$ and in this respect for the one-humped camel only a brief general description was given. The present investigation was carried out to get detailed and sufficient description of the origin, course, situations, arrangements and branches of the arteries supplying blood to the head.

\section{Materials and methods}

Five head-neck regions of adult one-humped camels were collected immediately following slaughter and injected with $10 \%$ formalin. After fixation, a solution of red latex was injected through both common carotid arteries via a cannula. This injection was performed under hand pressure and was stopped when the small vessels in the conjunctiva became visible to the naked eye. Both sides of each specimen were carefully dissected.

\section{Results}

The common carotid artery was found to lie between the trachea and the esophagus and to ascend towards the intermandibular and retromandibular regions. This artery appears as a rather regularly cylindrical conduit with a diameter of 6 to $8 \mathrm{~mm}$. At the level of the angle of the mandible, Etemadi ${ }^{5}$ The common carotid artery is embedded in the parotid gland (Figure 1)

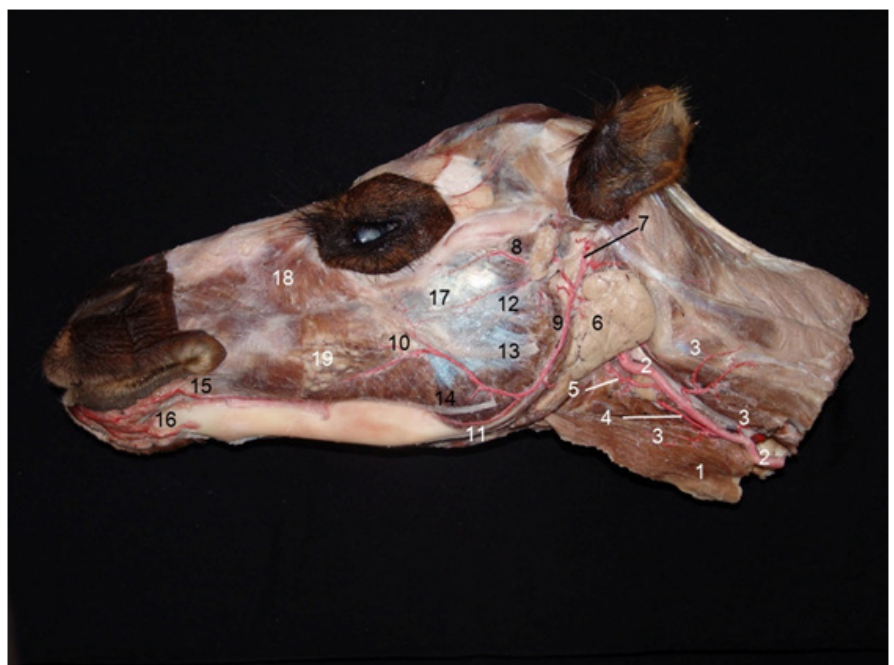

Figure I Arteries of the head (Superficiel layer, lateral view). I- M. sternocephalicus, 2- A. carotis communis, 3- R. musculares, 4- A. thyroideus media, 5- A. thyroidea cranialis, 6- Glandulae mandibularis, 7- A. auricularis caudalis, 8- A. transversa faciei, 9- A. facialis, I0- A. facialis, rami dorsalis, I I- A facialis, rami ventralis, I2- Nervi facialis, rami dorsalis, I3- Nervi facialis, rami ventralis, 14- Nervi transversus faciei, I5- A. labialis inferior, 16- R. mentales, 17- M. masseter, 18- M. malaris, 19- Glandulae salivariae.
Volume 5 Issue 5 - 2018

\section{Hassen Jerbi,' William Pérez²}

'Service d'Anatomie Des Mammifères Domestiques, Ecole Nationale De Médecine Vétérinaire Sidi Thabet, Tunisie

${ }^{2}$ Facultad de Veterinaria, Universidad de la República, Uruguay

Correspondence: Jerbi Hassen, Service d'Anatomie Des Mammifères Domestiques, Ecole Nationale de Médecine Vétérinaire Sidi Thabet CP 2020,Tunisie, Email hassen_jarbi@yahoo.fr

Received: October 01, 2018 | Published: October 23, 2018

At the level of the axis, it gives off ventrally, the cranial thyroid artery to the cranial part of the thyroid gland, the middle thyroid artery to the middle part of the thyroid gland, and dorsally, the occipital artery which passes through the foramen alare and anastomoses with the vertebral artery (Figure 2) (Figure 3). Under the wing of the atlas, the common carotid artery is continued by the external carotid artery (Figure 2) (Figure 4).

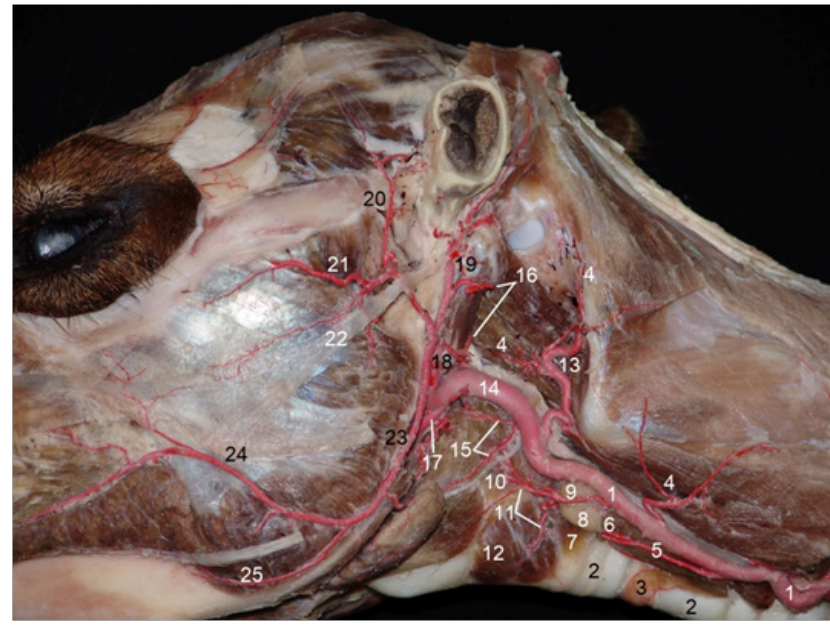

Figure 2 Arteries of guttural pouch area, with mandibular salivary gland removed (Superficiel layer, lateral view). A. carotis communis, 2- Trachea, 3- Isthmus, 4- R. musculares, 5- A. thyroideus media, 6- A. laryngea caudalis, 7- M. cricopharyngeus, 8- Lymphonodus cervicales profundi craniales, 9- A. thyroidea cranialis, I0- R. pharyngeus ascendens, II- R. laryngea cranialis, I2M. thyropharyngeus, I3-A. occipitalis, I4- A. carotis externa, I5- R. pharyngeus descendens, 16- R. parotidei, 17- A. lingualis, 18- A. temporalis superficialis, 19- A. auricularis caudalis, 20- A. auricularis rostralis, 2 I- A. transversa faciei, 22- Nervi facialis, 23- A. facialis, 24- A. facialis, rami dorsalis, 25- A. facialis, rami ventralis.

The external carotid artery is an artery of considerable caliber. It is 7 to $8 \mathrm{~cm}$ long and measures 6 to $7 \mathrm{~mm}$ in diameter. It presents both a cranial and caudal convexity (Figure 3 ). In its course, it goes along the side of the larynx, arrives on the caudal edge of the big branch of the hyoid bone and continues between this bone and the stylohyoid 
muscle. It divides under the caudal venter of the digastric muscle in a very wide angle into the superficial temporal artery and the maxillary artery (Figure 5).

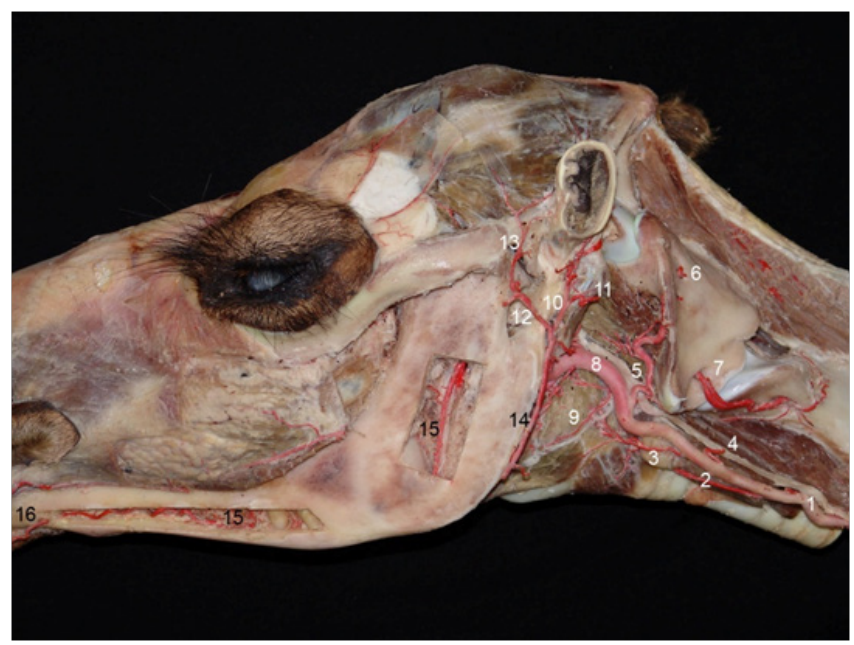

Figure 3 Arteries of the head (Middel layer, lateral view). I- A. carotis communis, 2- A. thyroideus media, 3- A. thyroidea cranialis, 4- R. musculares, 5- A. occipitalis, 6- R. occipitalis, 7- A. vertabralis, 8- A. carotis externa, 9- R. pharyngeus descendens, 10- A. auricularis caudalis, II- R. musculares, I2A. auricularis rostralis, 13- A. temporalis superficialis, I4- A. facialis, I5- A. alveolaris mandibularis, 16-A. mentalis.

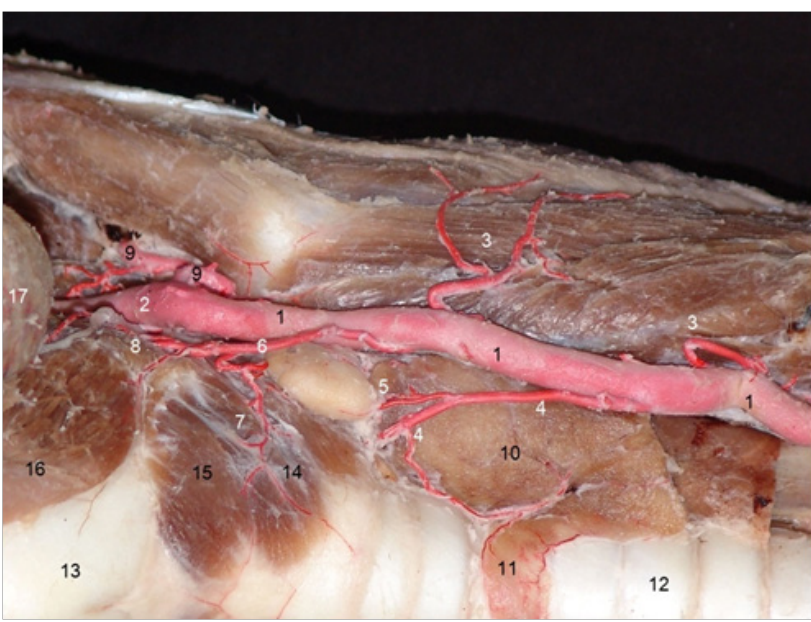

Figure 4 Collateral of the common carotid, (Ventral view). I- A. carotis communis, 2- A. carotis externa, 3- R. musculares, 4- A. thyroideus media, 5- R. laryngea caudalis, 6- A. thyroidea cranialis, 7- R. laryngea cranialis, 8- R. pharyngeus ascendens, 9- A. occipitalis, I0- Glandulae thyroidea, IIIsthmus, 12- Trachea, I3- Cartilago throidea, I4- M. cricopharyngeus, 15- M. cricothyroideus, 16- M. thyropharyngeus, 17- Lymphonodus mandibularis.

Moreover, at this level, this artery divides in depth into the internal carotid artery and the condylar artery (Figure 6). The internal carotid artery crosses the caudal border of stylohoid muscle and ascends to the base of the skull. During this part of its course, the internal carotid artery is related to the pharynx, pre-vertebral muscles and the soft tissue medially Etemadi ${ }^{5}$ (Figure 5) (Figure 6). The proximal segment of the internal carotid artery is divided into its terminal branches, the middle and rostral cerebral arteries (Figure 7). The condylar artery supplies the dura mater and the tissues of the epidural space in the immediate vicinity (Figure 6)

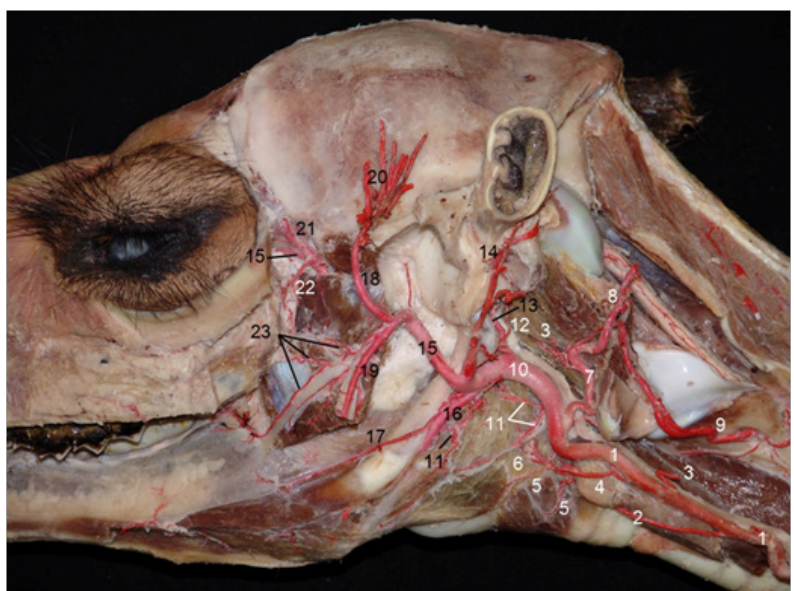

Figure 5 Arteries of the head and brain (Deep layer, lateral view). I- A carotis communis, 2- A. thyroideus media, 3- R. musculares, 4- A. thyroidea cranialis, 5- R. laryngea cranialis, 6- R. pharyngeus ascendens, 7- A. occipitalis, 8- R. occipitalis, 9- A. vertabralis, I0- A. carotis externa, II- R. pharyngeus descendens, I2-A. condylaris, I3-A. carotis interna, I4- A. auricularis caudalis, I5- A. maxillaris, 16- A. lingualis, I7- A. sublingualis, I8- A. temporalis profunda caudalis, 19- A. alveolaris mandibularis, 20- R. musculares, 21 - A. ophthalmica externa, 22- A. buccalis, 23- A. palatina ascendens.

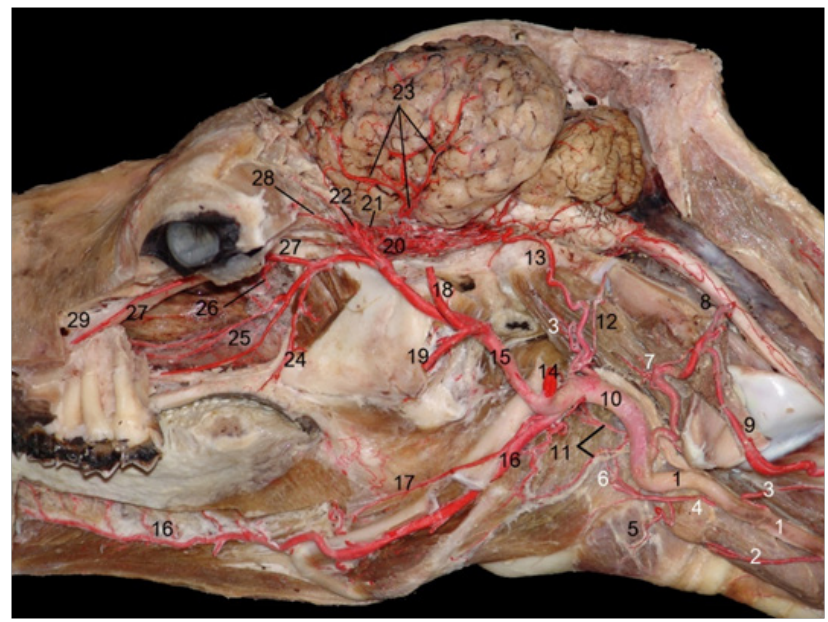

Figure 6 Arteries of the head with mandibular removed (Deep layer, lateral view). I- A. carotis communis, 2- A. thyroideus media, 3- R. musculares, 4A. thyroidea cranialis, 5- R. laryngea cranialis, 6- R. pharyngeus ascendens, 7- A. occipitalis, 8- R.occipitalis, 9- A. vertabralis, 10- A. carotis externa, IIR. pharyngeus descendens, I2- A. condylaris, 13- A. carotis interna, 14- A. auricularis caudalis, I5- A. maxillaris, 16- A. lingualis, I7- A. sublingualis, I8- A. temporalis profunda caudalis, 19- A. alveolaris mandibularis, 20- Extracranial part of the rete mirabile epidurale rostrale, 2I- Rete mirabile epidurale rostrale, 22- Rete mirabile ophthalmicum, 23- A. cerebri media, 24- A. palatina minor, 25- A. palatina major, 26- A. sphenopalatina, 27- A. infraorbitalis, 28- A. ophthalmica externa, 29- Nervi maxillaris.

The lingual artery is detached under a very acute angle in the space of the stylohyal bone and stylohyoid muscle meadows from the cranial extremity of the mandibular lymph node (Figure 5). The artery then goes forwards and downwards, always covered by the digastric muscle in its dorsocaudal portion, and laterally by the rostral edge of the hypopharyngeal muscle. Then, it penetrates into the hyoglossus muscle, to cross the totality of the tongue, Baron ${ }^{6}$ (Figure 5). 


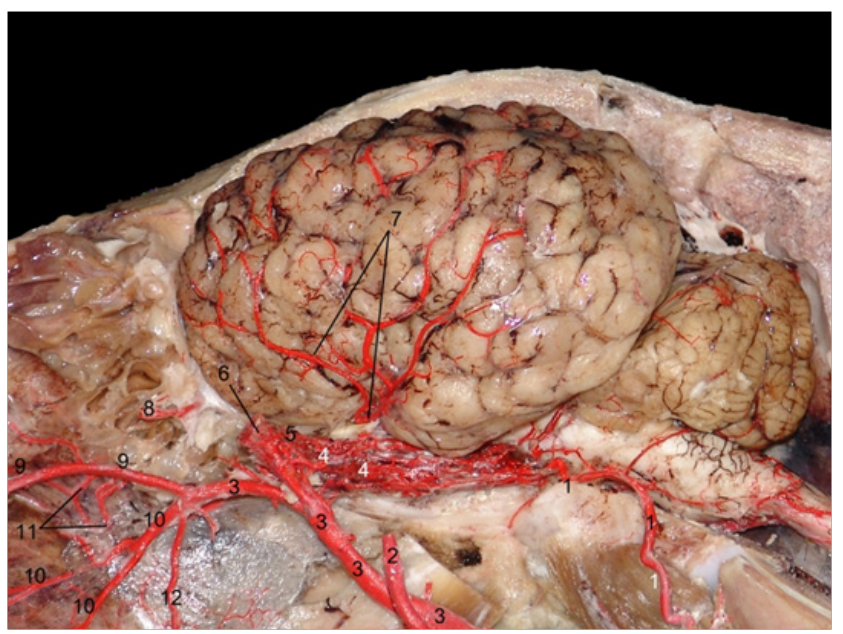

Figure 7 Cerebral arteries (Ventral view). I-A. carotis interna, 2-A.temporalis profunda caudalis, 3-A. maxillaris, 4- Extracranial part of the rete mirabile epidurale rostrale, 5- Rete mirabile epidurale rostrale, 6- Rete mirabile ophthalmicum, 7- A. cerebri media, 8- A. oftalmica interna, 9- A. infraorbitalis, I0- A. palatina major, II-A. sphenopalatina, I2- A. palatina minor.

The superficial temporal artery is the smallest and shortest of the endings of the external carotid artery. Covered at first by the parotid gland, it runs perpendicularly to the external carotid artery and goes on $2 \mathrm{~cm}$. Then, it divides according to an open angle in three branches: the transverse facial artery, the rostral auricular artery and the facial artery (Figure 2).

The maxillary artery proceeds from its origin between the medial pterygoid muscle and the pharynx toward the pterygoid fossa, Badawi et al. ${ }^{7}$ It gives off the alveolar artery, the buccal artery and the middle meningeal artery (Figure 5). The first artery gives supplies for temporal muscle and pterygoid muscles before it enters the mandibular foramen. The second artery, supplies the dorso-caudal buccal region. The third artery passes through the oval foramen to supply the meninges Kieltyka-kurc et al. ${ }^{8}$ At the level of the foramen orbito-rotundum, the maxillary artery detaches a vessel which divides immediately into several small branches. Some of this twings pass rostrally to participate in the formation of the rete mirabile ophthalmicum Ocal et al. ${ }^{9}$; Wang ${ }^{10}$ (Figure 7).

The remaining branches, the rami rostrales and rete mirabile epidurale rostrale, follow a course caudally with the maxillary nerve, Wang ${ }^{10}$ (Figure 6). Then they get through the foramen orbito-rotundum and contribute to the formation of the rete mirabile epidurale rostrale Jerbi et al. ${ }^{11}$ Next, the maxillary artery continues its course towards the maxillary foramen where its divides into the infraorbital artery and the descending palatine artery (Figure $6 \& 7$ ).

\section{Conclusion}

The present investigation reveals quite a number of interesting features characteristic to the species. In the order Artiodactyla, the pattern of the arterial supply to the head of one-humped camel differs considerably from other ruminants. At the level of the axis, the common carotid artery gives off three branches to the thyroid gland. The maxillary artery has an entirely extraosseous course.

\section{Acknowledgements}

None.

\section{Conflict of interest}

The authors declare there is no conflict of interest.

\section{References}

1. Tayeb MAF. A study on the blood supply of the camel's head. Br Vet J. 1951;107(4):147-155.

2. Smuts MMS, Bezuidenhout AJ. Anatomy of the dromedary. New York: Clarendon Press, Oxford University Press; 1987:230.

3. Blanco DB, Vasquez JM, Rivero MA, et al. Computed tomography of the brain and associated structures of the one-humped camel (Camelus Dromedarius). Journal of applied animal research. 2015;43(2):218-223.

4. O'Brein HD. Cranial arterial patterns of the alpaca (Camelidae: Vicugna pacos). R Soc Open Sci. 2017;4(3):1-12.

5. Etemadi AA. Carotid body of Camelus Dromedarius. Acta anat.1975;92(1):110-121.

6. Barone R. Anatomie Comparée des Mammifères Domestiques. Angiologie. Paris, Vigot Fréres. 1996:904.

7. Badawi H, El-Shaied M. Kenawy A. The arteria maxillaris of the Camel (Camelus Dromedarius). Anat Histol Embryol. 1977;6(1):21-28.

8. Kieltyka-kurc A, Frackowiak H, Zdun M, et al. The arteries on the base of the brain in the camelids (Camelidae). Italian Journal of Zoology. 2014;81(2):215-220.

9. Ocal MK, Erden H, Ogut I, et al. A quantitative study on the retial arteries in one-humped camels. Ann Anat. 1998;180(4):369-371.

10. Wang JL. The arterial supply to the eye of the Bactrian Camel (Camelus bactriaus). Vet Res Commun. 2002;26(7):505-512.

11. Jerbi H, Khaldi S, Perez W. Morphometric study of the rostral epidural rete mirabile in the dromedary (Camelus dromedarius, Linnaeus 1758). Int J Morphol. 2016;34(4):1429-1435. 